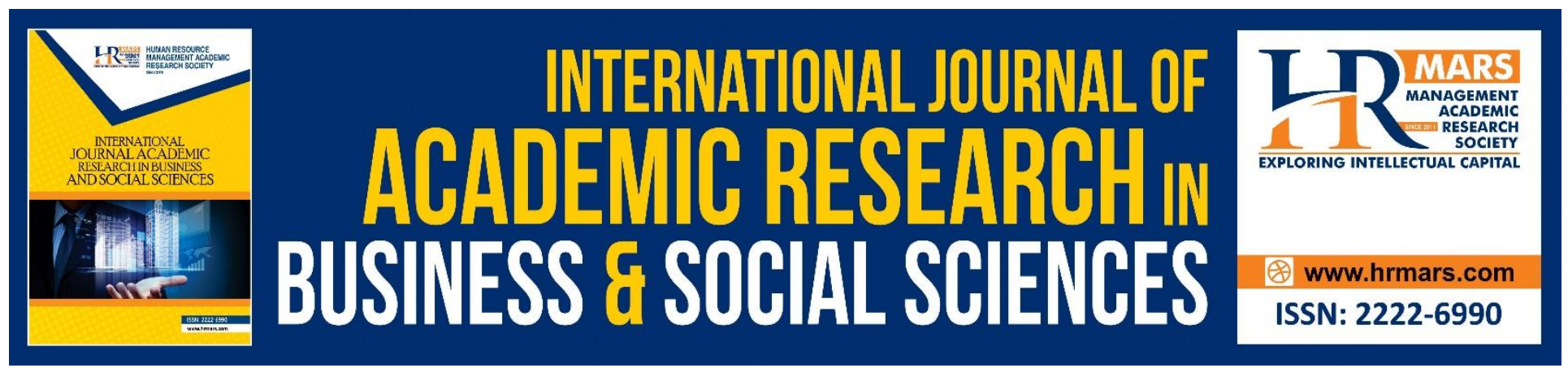

\title{
The Impact of Entrepreneurial Leadership and Innovation Process on Innovation Performance
}

Nurul Indawati, Andre Dwijanto Witjaksono, Anang Kistyanto

To Link this Article: http://dx.doi.org/10.6007/IJARBSS/v8-i9/4639

DOI: $\quad 10.6007 /$ IJARBSS/v8-i9/4639

Received: 06 August 2018, Revised: 04 September 2018, Accepted: 29 September 2018

Published Online: 20 October 2018

In-Text Citation: (Indawati, et. al., 2018)

To Cite this Article: Indawati, N., Witjaksono, A.D., \& Kistyanto, A. (2018). The Impact of Entrepreneurial Leadership and Innovation Process on Innovation Performance. International Journal of Academic Research in Business and Social Sciences, 8(9), 573-581.

Copyright: (C) 2018 The Author(s)

Published by Human Resource Management Academic Research Society (www.hrmars.com)

This article is published under the Creative Commons Attribution (CC BY 4.0) license. Anyone may reproduce, distribute, translate and create derivative works of this article (for both commercial and non-commercial purposes), subject to full attribution to the original publication and authors. The full terms of this license may be seen

at: http://creativecommons.org/licences/by/4.0/legalcode

Vol. 8, No. 9, September 2018, Pg. $573-581$

http://hrmars.com/index.php/pages/detail/IJARBSS

JOURNAL HOMEPAGE

Full Terms \& Conditions of access and use can be found at http://hrmars.com/index.php/pages/detail/publication-ethics 


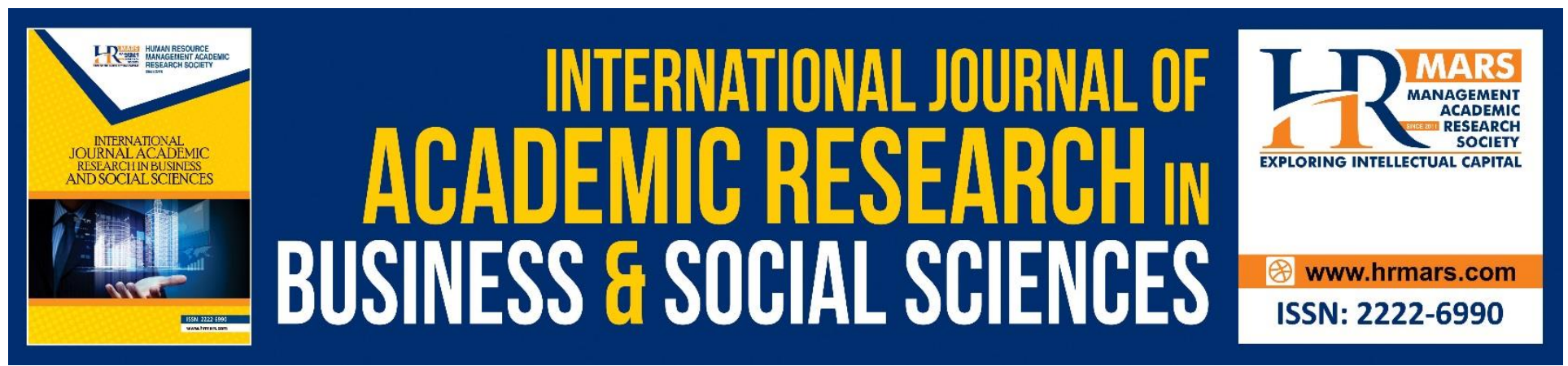

\title{
The Impact of Entrepreneurial Leadership and Innovation Process on Innovation Performance
}

\author{
Nurul Indawati \\ Jurusan Manajemen, Universitas Negeri Surabaya, Surabaya \\ Andre Dwijanto Witjaksono \\ Jurusan Manajemen, Universitas Negeri Surabaya, Surabaya \\ Anang Kistyanto \\ Jurusan Manajemen, Universitas Negeri Surabaya, Surabaya
}

\begin{abstract}
The aim of this research is to understand the impact of entrepreneurial leadership to innovation performance through an innovation process. The employee of private companies and state-owned enterprises in Surabaya completed measures of entrepreneurial leadership, innovation process, and innovation performance. The results of this study show that Hypotheses $\mathrm{H} 1 \mathrm{a}-\mathrm{H} 1 \mathrm{~d}$ have a positive relationship between entrepreneurial leadership (EL) and innovation process. The findings also support hypotheses $\mathrm{H} 2 \mathrm{~b}$ and $\mathrm{H} 2 \mathrm{c}$ (between Idea Selection to Innovation Performance and Idea Development to Innovation Performance). However, Hypotheses H2a and H2d were not supported.

Keywords: Entrepreneurial Leadership, Innovation Process, Innovation Performance.
\end{abstract}

\section{Introduction}

In the globalization era, economy based entrepreneurial could be more effective, because everyone is given the opportunity to do the best and fastest. Changes in the business environment at the regional level together with the implementation of the AEC makes companies needed an entrepreneurial leadership (entrepreneurship based leadership). Entrepreneurial leadership is leadership that involves organizational changes, as opposed to the leadership to maintain the status quo. In addition, in order to win market competition both at national and international market, the continuous innovation needs to be done by all companies in Indonesia. Innovation management has an important role in the growth of the company and control of the competition. Innovative means someone who likes to make improvements, presenting something new/different unique with existing ones. Thus, innovative attitude is important to be owned by an entrepreneur.

Several studies of entrepreneurial leadership as according to Currie, et. al., (2008) in the journal entitled "innovation, proactive, and vision are three integrated dimensions of leadership and entrepreneurship." Said product innovation and entrepreneurial leadership is a process that is 
holistic, complimentary life. According to Shane, et. al., (2000) in the journal entitled "Entrepreneurial Leadership: Developing cross-cultural constructs." Saying Entrepreneurial leadership and product innovation has a very close relationship in creating a superior product. Mehrad, et. al., (2011) says that the Entrepreneurial leadership is evident in product and process innovation.

Basrowi (2009) says that the ability of people in creativity can also be applied in the entrepreneurial, a person's ability to lead should be offset by a particular behavior is also known as the entrepreneurial dimension of innovation. Entrepreneurial leadership aspects are Able to Motivate, Visionary, Proactive, innovativeness, Risk Taking, Achievement Oriented, Persistence. While aspects of the product innovation are radical and incremental innovation Innovation. Leaders must dare to think differently to create opportunities and realize the dream of the organization. Almost every aspect of work is influenced by, and dependent on the leadership. That is, the leadership determines the success of an organization in building the capability and competence to win the competition (sustainable competitive advantage).

The purpose of this study to understand the impact of entrepreneurial leadership to innovation performance through innovation process.

\section{Literature Review}

\section{Entrepreneurial Leadership (EL)}

Entrepreneurial leadership is the process of Influencing organization through direct involvement in leading and creating value for stakeholders by bringing together a unique innovation and package of resources to respond to a Recognized opportunity (Darling, et. al., 2007). Gupta, et. al., (2004) indicated resources EL that creates visionary scenarios to assemble and Mobilize a supporting cast of participants who become committed by the vision of the discovery and exploitation of strategic value creation. Good entrepreneurial leadership can also improve a company's performance (Kistyanto, et. al., 2018; Wardoyo, et. al., 2018). There are five dimensions of entrepreneurial leadership by Musa and Fontana (2017) :

(i) Strategic dimension with the capability to offer section determine the organization system in a manner comprehensively taking into account its resources, people, and strategy, as well as the business model that an organization adopts.

(ii) The offer section communicative dimension with how such a vision of future possibilities is shared throughout the organization. It deals with the capability to persuade members of the organization, to manage conflicts, and to foster knowledge management by understanding emotions in social interactions (Subramanian \& Nilakanta, 1996; Szulanski, 1996).

(iii) Offer section with the motivational dimension of human action within the organization that Affects both motivation and cognition of people in the organization. Gupta, et. al., (2004) stated that entrepreneurial leadership is all about managing and instituting transformational and social enactment through positive motivation.

(iv) Personal and/or organizational dimension -aimed at factors relating to creativity, stability, proper resource allocation (job fit), and discipline.

\section{Innovation Process}


INTERNATIONAL JOURNAL OF ACADEMIC RESEARCH IN BUSINESS AND SOCIAL SCIENCES Vol. 8, No. 9, Sept. 2018, E-ISSN: 2222-6990 @ 2018 HRMARS

Innovation or innovation management process as an active and conscious process of an organization's control, and execution of activities that lead to innovation (Hansen and Birkinshaw, 2007). There are four phases of innovation process the first is /dea generation offer section with the process of generating ideas for new products (goods and/or services, in general). The second is Idea selection offer section with the screening of Reviews those new concepts based on an organization of strategic orientation and taking into account the organization's resource allocation conditions and objectives. Third, Idea development offer section with converting ideas into viable products based on known best practices. The last is Idea diffusion, offer section with delivering new innovative products to end customers. The goal of innovation management/innovation process is to Ensure that an organization is Able to continuously provide new innovative products and services to end customers, as well as business model innovation to maintain the organization's competitiveness by having a sustained innovation performance.

\section{Innovation Performance (IP)}

Fontana in Aryanto, Fontana, Afif (2015) Described and Examined innovation performance measurement based on the following dimensions:

(i) Internal Aspect of Innovation Performance (Internal Performance) measures the perceptual organizational innovativeness before, during and after an innovation process.

(ii) Technical Performance Refers to the organization ability to Realize creative and innovative ideas into real products, goods and/or services.

(iii) Commercial Performance Refers to the organization abilities in diffusing or distributing the innovative products in the market. It basically indicates that the innovation process has produced goods and/or services that can be sold to the market.

(iv) Social Performance Refers to the positive impact that an organization creates through Reviews their innovation input, process, and output not only to the pertinent stakeholders in particular but Also to the community and society in general as part of Reviews their corporate social responsibility as well as Reviews their corporate-shared-values' actions toward the community and society at large. (v) Economic Performance offer section with the financial performance of an innovative output that has passed the commercialization phase in particular or in general the diffusion phase.

\section{Research Questions}

H1a) Entrepreneurial leadership has a positive relationship with Idea Generation.

H1b) Entrepreneurial leadership has a positive relationship with Idea Selection.

H1c) Entrepreneurial leadership has a positive relationship with Idea Development.

H1d) Entrepreneurial leadership has a positive relationship with Idea Diffusion.

H2a) Idea Generation has a positive relationship with Innovation Performance.

$\mathrm{H} 2 \mathrm{~b})$ Idea Selection has a positive relationship with Innovation Performance.

H2c) Idea Development has a positive relationship with Innovation Performance.

H2d) Diffusion Idea has a positive relationship with Innovation Performance.

\section{Methodology}

Sample and Procedure 
INTERNATIONAL JOURNAL OF ACADEMIC RESEARCH IN BUSINESS AND SOCIAL SCIENCES

Vol. 8, No. 9, Sept. 2018, E-ISSN: 2222-6990 @ 2018 HRMARS

The population used in this study is employees of private companies and state-owned enterprises in Surabaya. The sample was taken by convenience sampling technique.

\section{Measurement}

\section{Entrepreneurial Leadership (EL)}

EL is measured with 24 items of ELQ across the four dimensions of EL items, (1) Strategic dimension (STRAT) with 10 items, (2) Communicative dimension (COMM) with 5 items, (3) Motivational dimension (Motiv) with 5 items, and (4) Personal/organizational dimension (PRESS) with 4 items. The ELQ was developed by Musa and Fontana (2014) to measure employees' perceptions of Reviews their organization's entrepreneurial leadership.

\section{Innovation Process}

Hansen and Birkinshaw (2007) define management or process innovation as an activity and process control consciousness of the organization and implementation of activities that lead innovation. Hansen and Birkinshaw further describe the process of innovation as a result, a three-stage process that involves up with ideas, discuss ideas, and to spread the idea of the concept developed. This study combines innovation process framework that viewed the innovation process as a four-stage process that includes idea generation (Igen), idea selection (Isel), the idea of development (Idev), and the idea of diffusion (IDIFF). Innovation process was measured with thirteen items of IPQ across the four dimensions of innovation process.

\section{Innovation Performance (IP)}

Based on the definition of innovation De Meyer and Garg (2005) which was then developed to cover not only economic performance but also social performance (Fontana, 2009), in Aryanto, Fontana, Afif (2015) describe and explain innovation performance is measured based on the following dimensions : (I) Internal Aspect of Innovation Performance (Internal Performance), (ii) Technical Performance, (iii) Commercial Performance, (iv) Social Performance, (v) Economic Performance

\section{Result}

\section{Descriptives Statistics}

Respondents of this study were employees of private companies and state-owned enterprises (SOE) in Surabaya. The number of respondents was 50 employees with 37 (74\%) male employees and 13 (26\%) women employees. Respondents aged 21 -30 years were 28 employees (56\%) and aged 3140 as many as 22 employees (44\%).

\section{Construct Validity and Reliability}

Table 1. Results Evaluation After Convergent Validity 
INTERNATIONAL JOURNAL OF ACADEMIC RESEARCH IN BUSINESS AND SOCIAL SCIENCES Vol. 8, No. 9, Sept. 2018, E-ISSN: 2222-6990 @ 2018 HRMARS

\begin{tabular}{lccc}
\hline Construct & $\begin{array}{c}\text { Cronbach's } \\
\text { alpha coefficient }\end{array}$ & $\begin{array}{c}\text { composite } \\
\text { Reliability }\end{array}$ & AVE \\
\hline entrepreneurial Leadership & 0.823 & 0.867 & 0.525 \\
Idea Generation & 0.635 & 0.808 & 0.679 \\
Idea Selection & 0.625 & 0.747 & 0.597 \\
Idea Development & 0.613 & 0.804 & 0.673 \\
Idea Diffusion & 0.663 & 0.750 & 0.605 \\
Innovation Performance & 0.869 & 0.901 & 0.604 \\
\hline
\end{tabular}

The composite reliability coefficient was more than 0.70 , as well as the cronbach's alpha coefficient was more than 0.50 . Thus, all the constructs meet validity and reliability.

Structural Equation Modelling PLS (SEM PLS)

Latent Variable Correlation Matrix

In the sixth existing variables in the model have a marked positive correlation coefficient with a range of 0.739 to 0.916 . The correlation coefficient in the relationship between variables is significant because the critical value of the correlation coefficient in the sample size of 50 is 0.215 . Table 2 shows the matrix of correlations between variables.

Table 2. Matrix Correlation Between Variables

\begin{tabular}{lcccccc}
\hline & $\mathrm{EL}$ & Igen & Isel & Idev & IDIFF & IP \\
\hline entrepreneurial & - & & & & & \\
Leadership & & & & & & \\
Idea Generation & 0.795 & - & & & & \\
Idea Selection & 0.901 & 0.741 & - & & & \\
Idea Development & 0.916 & 0.726 & 0.903 & - & & \\
Idea Diffusion & 0.818 & 0.810 & 0.765 & 0.739 & & \\
Innovation & 0.954 & 0.751 & 0.956 & 0.943 & 0.782 & - \\
Performance & 0.953 & & & & \\
\hline
\end{tabular}

Testing Structural Model (Inner Model) 


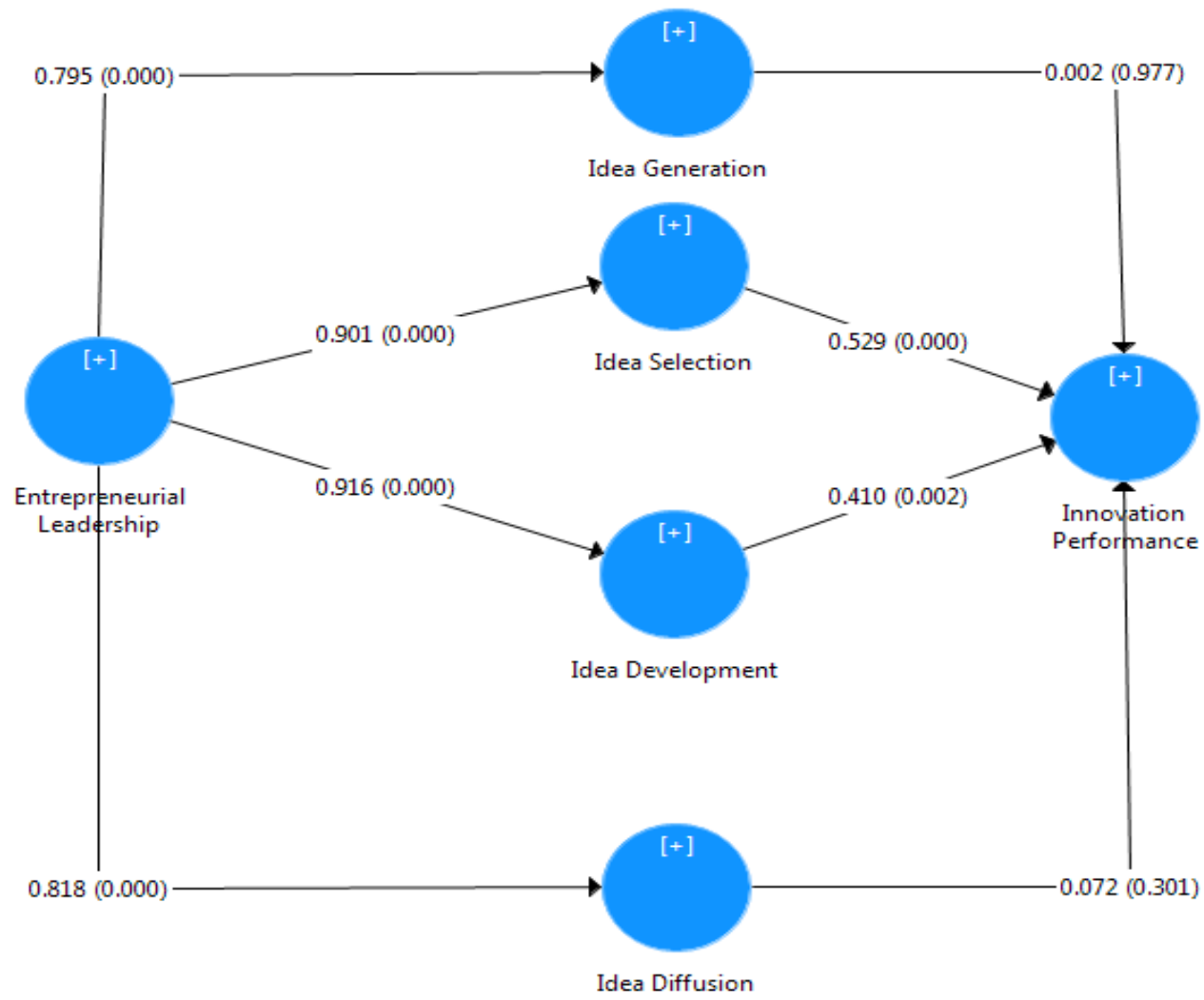

Figure 1. Hypothesis Model

Hypothesis testing is based on the results of the analysis of SEM PLS models that contain all the variables supporting the hypothesis test. Table 3 describes the path coefficient test results contained in the study.

Table 3. Coefficient Test Line On Inner Model

\begin{tabular}{clccccc}
\hline From & & To & $\begin{array}{c}\text { coefficient } \\
\text { Line }\end{array}$ & $\begin{array}{c}\text { Standard } \\
\text { deviation }\end{array}$ & P & Information \\
\hline EL & $==>$ & Igen & 0.795 & 0.031 & $<0.001$ & Significant \\
EL & $==>$ & Isel & 0.901 & 0.025 & $<0.001$ & Significant \\
EL & $==>$ & Idev & 0.916 & 0.022 & $<0.001$ & Significant \\
EL & $==>$ & IDIFF & 0.818 & 0.030 & $<0.001$ & Significant \\
Igen & $==>$ & IP & 0.002 & 0.041 & 0.977 & Not significant \\
Isel & $==>$ & IP & 0.529 & 0.086 & $<0.001$ & Significant \\
Idev & $==>$ & IP & 0.410 & 0.087 & $<0.001$ & Significant \\
IDIFF & $==>$ & IP & 0.072 & 0.041 & 0.301 & Not significant \\
\hline
\end{tabular}

Description: EL = Entrepreneurial Leadership; Igen = Idea Generation; Isel = Idea Selection; Idev = Idea Development; IDIFF $=$ Idea Diffusion; IP = Innovation Performance

The table and the figure above are described as follows:

1. Entrepreneurial leadership to idea generation has a coefficient with positive directions. Statistical results show the path coefficient of $0.795(p<0.05)$ this proves that entrepreneurial leadership 
has significant effect on idea generation. It means the relationship between entrepreneurial leadership and idea generation is supported (H1a Supported).

2. Entrepreneurial leadership against the idea selection has a coefficient with positive directions. Statistical results indicate the path coefficient of $0.901(p<0.05)$ this proves that entrepreneurial leadership has a significant effect on the idea selection. Thus the hypothesis H1b was supported.

3. Entrepreneurial leadership against the idea development has a coefficient with positive directions. Statistical results show that the path coefficient of $0.916(p<0.05)$ this proves that entrepreneurial leadership has a significant effect on idea development. Thus the hypothesis $\mathrm{H} 1 \mathrm{c}$ was supported.

4. Entrepreneurial leadership against the idea diffusion has coefficients with positive directions. Statistical results show that the path coefficient of $0.818(p<0.05)$ this show that entrepreneurial leadership has a significant effect on the idea diffusion. (H1d supported)

5. Idea generation towards innovation performance has the path coefficient of $0.002(p>0.05)$. This statistical result did not support the relationship between idea generation and innovation performance. Thus the hypothesis $\mathrm{H} 2 \mathrm{a}$ was not supported.

6. Idea selection towards innovation performance has the path coefficient of $0.529(p<0.05)$ this proves that idea selection has a significant effect on innovation performance. ( $\mathrm{H} 2 \mathrm{~b}$ was supported)

7. Idea development towards innovation performance has the path coefficient of $0.410(p<0.05)$ it shows that idea development has a significant effect on innovation performance. ( $\mathrm{H} 2 \mathrm{C}$ was supported).

8. Idea diffusion towards innovation performance has the path coefficient of $0.072(p>0.05)$ it means $\mathrm{H} 2 \mathrm{~d}$ was not supported (the relationship between idea diffusion and innovation performance).

\section{Conclusion}

Entrepreneurial leadership is important for an organization to foster the development of reviews their entrepreneurial leadership at all levels within the organization to ensure that innovation management/innovation process is managed effectively. Furthermore, the study found the positive relationship between idea selection and innovation performance as well as idea development and innovation. It means choosing the best idea that meets with the strategic organization will support innovation performance and developing a new idea into a viable product based on known best practices also will support the success of innovation performance. However, Idea generation and Idea diffusion were not supported innovation performance. The process of generating ideas for new products (goods and/or services, in general) not always accepted by all organization member clearly. Idea diffusion, for example, offers a section with delivering new innovative products to end customers. Idea diffusion was not supported innovation performance could happen when the customer prefers the original product/ services of the company.

\section{Acknowledgement}


INTERNATIONAL JOURNAL OF ACADEMIC RESEARCH IN BUSINESS AND SOCIAL SCIENCES

Vol. 8, No. 9, Sept. 2018, E-ISSN: 2222-6990 (C) 2018 HRMARS

1. Thank you to the Faculty of Economics who helped in financing this research.

2. Thanks to the respondents who participated in filling out the research questionnaire.

3. Thanks to all the research teams, colleagues, and all parties involved in the completion of this research.

\section{Corresponding Author}

Nurul Indawati

Jurusan Manajemen, Universitas Negeri Surabaya

Jl. Ketintang, Surabaya (60213)

\section{References}

Aryanto, R., Fontana, A., Afiff, A.Z. (2015). Strategic human resource management, innovation capability and performance: An Empirical Study in Indonesia Software Industry. Paper presented in the 2nd Global conference on business and Social Science-2015. GCBSS-2015, 17-18 September. Procedia-Social and Behavioral Sciences 211 (2015) 874-879.

Basrowi, (2009), Kewirausahaan untuk Perguruan Tinggi, Bogor: Ghalia Indonesia.

Currie, G, Humphreys, M., Ucbasaran, D. \& McManus, S. (2008). Entrepreneurial Leadership in the English Public Sector: Paradox or Possibility? Public Administration, 86, 4, 987-1008.

Darling, J., Keefe, M. and Ross, J. (2007). Entrepreneurial leadership strategies and values: Keys to operational excellence. Journal of Small Business and Entrepreneurship, 20(1), 41-54.

Fontana, A. (2009, 2010, 2011, 2016). Innovate We Can! Manajemen Inovasi dan Penciptaan Nilai. Jakarta: Gramedia Widiasarana Indonesia; Rev. Edition, Bekasi: Cipta Inovasi Sejahtera.

Gupta, V., MacMillan, I., and Surie, G. (2004). Entrepreneurial leadership: developing and measuring a cross-cultural construct. Journal of Business Venturing, 19(2), 241-260.

Kistyanto, Anang; Budiono; Nurul Indawati; Hujjatullah Fazlurrahman; Achmad Kautsar; and Zainur Rahman. (2018). Food Industry Performance: Entrepreneurial Leadership And Human Capital Perspective. International Journal of Mechanical Engineering and Technology (IJMET), Vol.9, Issue.6, pp. 1199-1208

Mehrdad, A., Hamidreza, M. R. (2011). Entrepreneurial Orientation and Innovation Performance: The Mediating Role of Knowledge Management. Mazandaran University St. Shahid Beheshti, Babolsar, Iran

Musa, S. and Fontana, A. (2014). Measuring entrepreneurial leadership in innovation management [Conceptual framework]. The ISPIM Asia-Pacific Innovation Forum 2014. Singapore: ISPIM 
INTERNATIONAL JOURNAL OF ACADEMIC RESEARCH IN BUSINESS AND SOCIAL SCIENCES

Vol. 8, No. 9, Sept. 2018, E-ISSN: 2222-6990 @ 2018 HRMARS

Shane S. And Venkataraman S., (2000). The promise of entrepreneurship as a field of research. I Academy of Management Review, 1 (25), 217-226

Subramanian, A., and Nilakanta, S. (1996). Organiztional innovativeness: Exploring the relationship between organizational determinants of innovation, types of innovation, and measures of organizational performance. International Journal of Management Science, 24(6), 631-647.

Szulanski, G. (1996). Exploring internal stickiness: Impediments to the transfer of best practice within the firm. Strategic Management Journal, 17, 27-43. 